\title{
Analysis of the Innovation Processes in the Sphere of Excursion Services of the Republic of Tatarstan
}

\author{
Postalyuk M.P. \\ Department of economic theory and innovation \\ University of management "TISBI" \\ Kazan, Russia \\ mp.44@mail.ru \\ Kulyagina N. G. \\ Department of accounting and taxation \\ University of management "TISBI" \\ Kazan, Russia \\ naadai@mail.ru
}

\author{
Rozanova L. N. \\ Department of economic theory and innovation \\ University of management "TISBI" \\ Kazan, Russia \\ ladarozanova@bk.ru
}

Vileghganina A.V.

Department of customs business

Kazan Kooperation Institute

Kazan, Russia

alsukazan@mail.ru

\begin{abstract}
The article analyzes innovative processes in the sphere of excursion services; analyzes innovations on the market of excursion services of the Republic of Tatarstan and Kazan, characteristic of preferences of tourists of classical and innovation forms of excursion activity is given. The growth of trips and excursions, the emergence of new forms, increased competition among tourist destinations, as well as the introduction of new information technologies became the characteristic feature of modernity. Excursions are the main modular part of tourist and museum activities and the main form of educational tourism. The main directions of innovation, the use of new types of equipment and technologies in traditional excursions, the emergence of new types of excursions: audio tours, excursions, quests, online, smart tours, 3D and art tours, etc., as well as new marketing techniques are analyzed. The article presents an analysis of innovative types of excursion activities in the Republic of Tatarstan and Kazan. In this regard, the leadership of museum tours are discussed in relation to the city.
\end{abstract}

Keywords-the innovation processes in the sphere of excursion services; the innovation methods of excursion work, Kazan; the Republic of Tatarstan

\section{INTRODUCTION}

The purpose of the study is to reveal the nature, content and forms of the innovative processes implementation in the sphere of excursion services; to identify trends and prospects of investment and institutional support of this activity on the regional level in the context of globalization, digitalization and innovation of economic processes in the tourism industry.

\section{LITERATURE REVIEW}

The genetic beginning of a General theory of innovation processes can be traced primarily in the works of G. Hospers, R. Smits, M. Laragy, E. and K. Arab Flanagan [1-6]. G. Hospers in his work "Joseph Schumpeter and his legacy in innovation research" analyzed the results of the legacy of Y. A. Schumpeter in terms of emerging theories of innovation in the framework of Neoclassicism, evolutionary theory. R. Smits in the article "the Doctrine of innovation in the XXI century: questions from economists" in the study of innovation identifies emerging "process" and "system" school. M. Laranja, E. and K. Arab Flanagan in his fundamental work "Policy in the field of science, technology and innovation: theoretical justification of regional policy on different levels" analyze existing (neoclassical endogenous growth theory, new growth theory, neomarshall cluster approach, the evolutionary structural approach, and systemic, institutional approach).

Analysis showed that, firstly, the dominant semantic load in these and other similar researches is the justification of the process and dynamism of accumulation, implementation and development of innovations, or, in other words, the process of innovatization in various spheres and levels of society: technical, technological, organizational, managerial, economic, institutional, political and, of course, tourism.

Secondly, in the existing researches the holistic approach considering process of realization of innovations is insufficiently used, at the same time, as variable system innovative interaction of business, the power and society, and as their uniform whole which finds the most adequate reflection in the category "innovatization" on mega -, macro -, meso -, micro - and nanolevels. At the same time, on the meso 
between subjects and objects, as well as personal and group relations.

In Soviet times there was a very serious approach to the preparation of excursions. Today the tour should also have mandatory characteristics: definite duration, presence of a tour group and a qualified tour guide, tour route, clearly defined theme which is the backbone of the event, etc.

The process of preparing a new excursion is a serious and long process based on setting goals and objectives of the excursion, studying and selecting excursion objects, studying relevant literature, expositions and museum collections, consulting specialists, drawing up a technological map of the excursion, etc.

Pedagogical principles must become the basis of preparation of the excursion: defined logic of the subject, consistency, regularity, clarity and accessibility of the presentation, clarity, emotion, and age-appropriate tourists.

Currently, innovation and informatization, introduction of new means of communication have seriously changed the minds of people and the sphere of social production as a whole.

Innovations in excursion activities are the answer to these challenges and are designed to respond to changing realities.

In the excursion business, the main directions of innovation can be considered new types of excursions, the use of new types of equipment and technologies in conducting traditional excursions, the emergence of new types of excursions: audio tours, quest tours, sightseeing storytelling, online, smart tours, 3D and art tours, etc., as well as new marketing techniques.

In general, innovations in the field of excursion activities can be divided into the following groups:

1. development of a new excursion product;

2. using of new technologies in the development of city and museum tours (audio guides, smart tours);

3. attraction of new resources not previously used as excursion objects (for example, abandoned construction, industrial or military facilities, etc.).);

4. development of new individual excursion products, getting closer to the client;

5. development of new excursions in the form of excursions-quests, excursion storytelling, 3D and art tours.

As it is conducted by the specialists, the most popular tours are the nature educational ones in cities and parks, excursions, elements of adventure tourism, sightseeing cruises, eco tours, theatrical museum and country activities, excursions, adventure, nature, entertainment tours, integrated urban and rural tourism.

Recent years, there are fundamentally new tours with nature excursions: for the elderly, sightseeing tours of picturesque places and interesting museum exhibits, special excursions for young people with a visit to fashion festivals, "fests", competitions, clothing shows, children's excursions 
A powerful impetus for the development of tourism in with animated elements, adventure tours and comprehensive excursions to cities and parks, individual excursions to meet the needs of a particular group or a particular individual tourist, and others.

\section{Animation is a popular innovation in excursion activities.}

Animated excursion programs may include historical theatrical performances and shows in which participants of the tour are involved, costume balls with the participation of historical characters, interactive quizzes that facilitate the perception of information.

3D tours give the possibility of full immersion. It is enough to download the appropriate program from the Internet and feel at the tourist site of interest.

Another innovation of European cities is excursion with using of cars with a special monitor which display the history of local sightseeing. Such cars work with GPS support.

Recently, quest tours have become a favorite destination of tourists. The most important difference of this type of excursion is the involvement of the tour participants in the gameplay, solving puzzles and problems of the relevant topic.

Quest tours are very similar to the game of the Soviet period "Zarnitsa". This kind of tours quickly gained popularity due to its gaming form and similarity with training, opportunity prove in an unusual for themselves specializations. This experience causes positive emotions, helps to unite the participants of the quest tour. One of new variants of the excursion quest is geocaching. It implies the creation of caches and their search by quest participants using the transmission of the coordinates with GPS-device.

The term virtual comes from English word which means "similar, indistinguishable." Virtual tour is a multimedia photo panorama which creates the effect of presence and the effect of walking.

Travel storytelling is defined as integrated marketing technology based on legends, myths, stories, urban stories, which become an independent attraction supplementing or even replacing traditional objects of tourist interest which substantiated through the items (souvenirs, tourist guides, etc.), imagery and iconic (street-art, iconographic documents, multimedia formats), text, online, and other tools for consumption by tourists [10].

Thus, we can consider a tremendous acceleration of innovation in the sphere of forms and technologies of modern excursions.

\section{DISCUSSION}

Today the Republic of Tatarstan is one of the most successful regions of Russia in economic and social terms, as well as one of the leaders among the regions of business entities of the tourism industry and tourist infrastructure. Tatarstan has a powerful tourist potential, including objects of national, cultural and historical heritage, ecological tourism, developed sanatorium and resort complex, as well as the most modern tourist infrastructure.
Tatarstan was the major historical, cultural and sports events of the world level: celebration of the 1000th anniversary of Kazan, preparation and holding of the world student games "Universiade-2013", the world Aquatics Championship in 2015, the World Football Championship in 2018 and the World skills Championship in 2019.

This is evidenced by the growth in the volume of sales of services in the tourism sector which has grown more than 4.5 times over the past 10 years. The volume of services rendered in the tourism sector (excluding related industries) for 11 months of 2017 amounted to 12253.2 million rubles, which is $13.1 \%$ more than in the same period of 2016. Kazan entered the TOP 10 best tourist destinations in Russia according to the portal Trip Advisor and analytical Agency "Turstat", and is on the 4th place at the end of the summer season 2017. Kazan has seen a $25 \%$ annual increase in the number of tourists since 2012. The number of foreign citizens who arrived in the Republic of Tatarstan increased by $11 \%$ compared to 2016 and amounted to 278183 people.

In Kazan over the past 5 years, the number of hotels has more than doubled and approached 230, and the number of rooms has increased from 5.5 to 13.5 thousand places [11].

To increase these indicators, Kazan has developed its tourist brand and slogan "thousand and one pleasures" and promotes it at state and international level. The specialized tourist portal "Visit Tatartsan" serves the same purposes.

According to the analysis, museums today are the leaders in the innovation of excursion activities in the Republic of Tatarstan.

Currently, the Museum network of the Republic of reserves with 35 structural units, 48-municipal with 43 branches. In total there are 140 Museum network units. Every year the number of museums in the region increases.

The main indicators of museum activity are growing: the units of the museum fund, the number of exhibitions organized by museums, the attendance of museums, the number of excursions. About a million Museum objects are included in the electronic catalog, which is $40.5 \%$ of the total number of the Museum Fund of the Republic.

There are museums of all types in the Republic: specialized, historical, art galleries, art museums, military, scientific, children's, as well as an Observatory and a planetarium

Currently, museums are expanding their functions - from the storage and research of artifacts to educational and often entertaining. Innovative computer and multimedia technologies help to assimilate a huge amount of useful information.

Interactive exhibitions have become usual for residents and guests of the Republic. Museums of Tatarstan actively use virtual reality technologies, multimedia installations, interactive and touch panels, sound holographic showcases, various immersion zones, etc. Tatarstan has 62 museums: 14 state museums and museum- 
A number of the youngest museums were immediately created as innovative. The museums of Kazan - "panorama City", natural history Museum of Tatarstan, a Museum of Islamic culture, the House of entertaining science and technology, Museum of illusions, the Giant's House, Museum of bread, Bulgarians, etc. Their number is about $5 \%$ of all museums of the Republic.

Most museums are actively introducing into the practice of their work various innovative methods of 3D-tours and questtours, excursion storytelling, art tours, excursions with master classes, etc.

Such excursions have long been in the practice of the National Museum of the Republic of Tatarstan, the housemuseum of E. A. Boratynsky, the Museum of Natural history of Tatarstan, the museum of chak-chak.

Thus, the national Museum of the Republic of Tatarstan offers interactive theatrical and costumed tours "Revived exposition" with the participation of craftsmen, soldiers, nobles and peasants. For children, the Museum has developed a tour with the house goblin of Museum. This brother of house goblin Kuzya lives in the Museum and knows how to captivate young lovers of history. In the course of this tour he offers to participate in a master class on the tape-harness technique of modeling dishes or master class "Patchwork Doll", etc.

The Museum offers guided tours-adventure with the elements of theatre "Treasures of Zilant" and "Pathfinder Museum".

House-Museum of E. A. Boratynsky, located in the estate of the writer in the historical part of Kazan, has developed an interactive tour "Christmas in noble families."

The Museum of natural history of Tatarstan is the only Museum and scientific-educational center in the Volga region, where full information about the geological history of our planet from the moment of its formation to the appearance of man is presented.

The Museum offers opportunities for interactive study of materials: here you can find out your weight on any planet of the Solar system, observe the planets and constellations through the eyepiece of an interactive telescope, participate in paleontological excavations, feed ancient fish in a prehistoric aquarium, communicate with the inhabitants of the Ice age, etc.

Most of sightseeing suggestions in the tourism market of the Republic of Tatarstan are classic in nature: sightseeing and thematic tours.

The most popular thematic tours are: tour of "Evening Kazan", the island town of Sviyazhsk, the Raifa monastery in the Temple of all religions, "Bolgar", in the city of Elabuga, tour to a natural Museum-reserve "ISKE Kazan", "Kazan Sports", etc.

Among the innovative tour products include the tour of the Innopolis . Innopolis is located in Verkhneuslonsky district of the Republic of Tatarstan at the confluence of two rivers Volga and Sviyaga. Innopolis University, Lyceum, school and special economic zone "innopolis" are located in the city. This is the youngest and one of the few cities built in post-Soviet Russia, one of the three science cities in the Russian Federation created for the development of information technologies and innovative high technologies. The intellectual core of the new city is Innopolis University. Here students receive higher education and participate in research in this area. Leading Russian and foreign experts teach in the University.

The number of new tour products include the classic excursions with elements of staging - the tour to Kazan Kremlin, old Tatar Sloboda with the guides in national Tatar costume: the Khan's reception, when guests meet Khan and Queen Syuyumbike, "F. I. Shalyapin in Kazan", "Petrov celebrations", etc.

Popular option for the first acquaintance with Kazan provides a bus with an audio guide. The route with stops at the most iconic sights of the city. By purchasing a daily ticket, you can go in/out at any vending point of the route.

\section{CONCLUSIONS}

1. Tourist and excursion industry in the modern world in the national economic systems is traditionally innovative. The basis for its development is primarily traditions - historical, national, religious and economic. These traditions are now constantly being refined and supplemented with innovations. These innovations exist both at the level of creation of new excursion and tourist products, and in a variety of ways and means of the organization and carrying out excursions. The market is becoming dynamic, with a high rate of saturation of its innovative products. Forms and means of manifestation of innovation excursion activities are digitalization, organization of audio tours, excursions, quests, excursions storytelling, online, smart tours, 3D and art tours, etc., as well as the use of new marketing techniques.

2. Behavioral Economics changes mission and goals of travel companies and systems. The function of the consumer of tourist services changes - from assimilation of the received information to active and creative participation in cognitive process.

It is important to preserve in the first place the content of the excursion activities, its educational and spiritual foundations, educational orientation. Digitisation should not not be used when it is really justified, and contributes to the achievement of the main cognitive and humane goals.

3. The peculiarity of the national-economic system of Tatarstan is the historical multiculturalism, multinational and multi-confessional population living here, the combination of Muslim and Christian traditions. Thus it creates rich opportunities for the development of cultural, historical, educational, ethnographic and other types of tourism.

Wise tourist policy is based on this traditional basis, supplemented with innovative forms and methods of organization, leads to a rapid growth of tourist indicators in the Republic of Tatarstan and Kazan. 
[7] Postaliuk M., Vagizova V., Postaliuk T. Implementation forms of institutional support of traditional national economies and innovative development. Investment Management and Financial Innovations. 2013, 4.

[1] Hospers Gert-Jan. Joseph Schumpeter and His Legacy in Innovation Studies. Knowledge, Technology \& Policy, Fall. 2005, vol. 18, 3, pp. 20-37.

[2] Larajaa M., Uyarra E., Flanagan K. Policies for science, technology and innovation: Translating rationales into regional policies in a multi-level setting. Research Policy. 2008, 37, pp. 823-835.

[3] Stits R. Innovation studies in the 21st century: Questions from a user's perspective. Technological Forecasting \& Social Change. 2002, 69, pp. 861-883.

[4] Qingrui, X., Jin C., Zhangshu Jingjiang X. L., Z. Gang, W. Yong. Total Innovation Management: a novel paradigm of innovation management in the 21st century. Journal of Technology Transfer. 2007, 32, pp. 9-25;

[5] Furman, J. L, Porter, M. E., Stern S. The Determinants of National Innovative Capacity. Research Policy. 2002, 31, pp. 899-933.

[6] Hirooka M. Innovation Dynamism and Economic Growth. A Nonlinear Perspective. Cheltenham, UK - Northampton, MA: Edward Elgar Publishing. 2006.

[8] Kasatova A., Postaliuk M., Khasanova A. The decomposition analysis institutional support of traditionalization and innovatization of Russian economy. Academy of Strategic Management Journal. 2016, vol. 15, 2, pp. 100-110

[9] Postalyuk M. P. Innovative relations in the economic system: theory, methodology and mechanism of implementation.- Kazan: publishing house Kazan. UN-TA. 2006, 420.

[10] Emelyanov Boris Ekskursovodov. Tutorial. pp. 5. URL: https://www.litmir.me/br/?b=32806\&p=5

[11] Alexsandr S. Kuznetsov. Russian Professor's meeting. Russian Journal of Physical Education and Sport. 2019, 14(1), pp. 17-22. DOI: 10.14526/2070-4798-2019-14-1-18-24

[12] The final collection of information and analytical materials for 2018/ / State Committee of the Republic of Tatarstan on tourism: website. URL: http://tourism.tatarstan.ru/rus/documents.htm?pub_id=1257754/. 